See discussions, stats, and author profiles for this publication at: https://www.researchgate.net/publication/345759329

\title{
The Closer, the Better? Comparing Advisory Councils at Different Government Levels
}

Article in Administration \& Society · November 2020

DOI: $10.1177 / 0095399720971601$

CITATION

1

3 authors:

Quim Brugué

Autonomous University of Barcelona

35 PUBLICATIONS 290 CITATIONS

SEE PROFILE

Basy Jorge Ruiz

Ey Spanish National Research Council

15 PUBLICATIONS 177 CITATIONS

SEE PROFILE

Some of the authors of this publication are also working on these related projects:

Project Explicando Actitudes Sosegadas hacia los Inmigrantes en España (EASIE) View project

Project Collective Production of Discourse and the Qualitative School of Madrid View project
READS

88

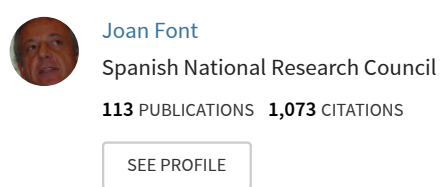




\section{The closer, the better? Comparing advisory councils at different government levels ${ }^{1}$}

Quim Brugué (Universitat de Girona)

Joan Font (IESA-CSIC)

Jorge Ruiz (IESA-CSIC)

Advisory councils exist at diverse government levels, making them especially appropriate to address the discussion about scaling up participatory institutions, by comparing their differences across different government levels.

We analyze the characteristics of advisory councils in Spain, where they are quite similar at the national, regional and local levels, allowing a controlled comparison of their functioning and results.

Results show similarities across territorial levels, but also signs of a better performance of the local and regional ones, especially regarding the satisfaction of participants. Relational goods and different understandings of what policy influence means are crucial explanations of these patterns.

Cite as Brugué Q, Font J, Ruiz J. The Closer, the Better? Comparing Advisory Councils at Different Government Levels. Administration \& Society. November 2020.

doi:10.1177/0095399720971601

\footnotetext{
${ }^{1}$ This work was supported by Spanish Ministry of Economy and Competitiveness: Grant Number CSO2015-66026-R
} 


\section{Introduction}

Efforts to strengthen democratic quality through the intensification of citizen participation often began with formal mechanisms to organise citizen participation, such as regulations and councils, and evolved towards more innovative ways, like participatory budgeting or citizen juries. These newer and more attractive institutions, which seemed to make more ambitious democratic promises (Smith, 2009), have attracted the most attention in the recent decades.

However, one of the most promising case studies of participatory institutions is based on Chicago advisory councils (Fung, 2004). The interesting results of this case are in sharp contrast to less optimistic assessments made in other contexts (Sintomer and Maillard, 2007; Hendriks et al, 2013). Are these apparently contradictory results due to the exceptionality of the Chicago case? Is it related to their bottom-up institutional design, to their local character, or to particular US characteristics, for example?

Today, Advisory Councils (ACs) are one of the most frequent participatory institutions in many parts of the world and at all governmental levels: municipalities, regions, and at national level (Campos and Gonzalez, 1999; Carvalho and Teixeira, 2000; Fobé et al, 2013). This is also the case in Spain, the universe we are analysing, where they have existed since the late '80s (Navarro, 2004) and are present at different territorial levels. 
Our aim here is to clarify the extent to which the differences in the operation and results of the ACs can be explained according to the territorial scale in which they work. In other words, do municipal councils, regional councils and national councils operate in the same way, and do they achieve the same results? In the event that they do not, does the territorial level variable explain these differences, or are other institutional design characteristics more important for understanding them?

To address this question, the paper is organised into five sections. Firstly, we develop a brief theoretical framework where we present our universe of analysis and discuss the potential influence of the territorial variable in the functioning of participatory institutions. Secondly, we explain the sources of information and the methodology used to generate the quantitative and qualitative empirical materials. Thirdly, we present the results. The quantitative section is built on a database created from a broad sample of councils. It shows more similarities than differences, but also a greater degree of satisfaction among local and regional participants. The qualitative section, carried out through the analysis of semi-structured interviews with participants in 10 ACs, helps to explain why this happens through two main mechanisms: relational goods and the differing interpretations of what policy impact means. The final section discusses the results and their implications in our understanding of democratic innovations and their prospects for scaling up.

\section{Theoretical framework}

2.1. Defining the universe of analysis 
ACs are a type of participatory institution based on the role played by associations. These councils are specifically designed to channel the voice of organised civil society and stakeholders. Some of the theories of democracy recognise the strengthening of civil society associations as one of the main ways to enrich democracy and channel citizen participation in public decisions (Warren 2001, Christiansen et al 2010). In this context, ACs are understood as places of public debate, where a deliberative logic should prevail. However, these institutions also aim to influence real decision-making, which means that voting and the use of aggregative logics is also required. As a result, they become a particularly interesting universe where some of the crucial dilemmas and trade-offs between these two democratic logics (deliberative and aggregative) become visible (Mansbridge, 1980).

Our operational definition of ACs covers three basic characteristics. Firstly, they are recognised institutionally as a space for public debate on a particular topic. This means that the AC may have been created by public administrations or through bottom-up processes (Cooper and Musso, 1999; Bolitho, 2013), but either way has gained recognition as a legitimate place for policy debate. Secondly, they have been created with a vocation of permanence and not for resolving a specific matter. Thus, compared to other democratic innovations, they tend to be highly institutionalised, with permanent structures and rules. Finally, they must include the presence of citizens, usually through the associations that represent them. 
These councils are therefore embedded within public institutions, although they are largely made up of representatives from organised civil society. They usually operate through plenaries and working groups, and their functions are varied, including acting as a space to develop public debates; they represent a body that can be formally consulted by the institutional authorities or provide advice without previous request; and they serve as a watchdog for governmental actions developed in a specific area of public policy. Part of their activity is developed through bottom-up processes, following their own agenda, and at other times they answer requests from public administrations. In some cases, they may have the capacity to take final decisions, but most of them only play an advisory role. This is the reason why the traditional Arnstein (1969) article places them at the bottom of the participatory scale, in the "manipulation" category.

These ACs materialise in abundance in the reality of many public administrations. Their exact name, functions, operational details and the frequency and territorial distribution of their existence changes from country to country, but similar versions of this institution exist in many parts of the world, from the Americas (Berry et al, 1993; Serdult and Welp, 2015; Pogrebinschi and Ryan, 2017), to Asia (Campos and Gonzalez, 1999; Bolitho, 2013) and Europe (Sintomer and Maillard, 2007; Christiansen et al, 2010). Despite their various names, most of them employ the word "council", suggesting a collective and permanent character, and although they have different practical roles, the majority of them take on an advisory role, at least formally. A certain degree of public debate occurs in them, but because the level of deliberation that occurs in them is what we aim to establish empirically, we choose to emphasise their formal advisory role in the chosen denomination, following other European cases (Fobé et al, 2013). 
ACs are an especially interesting institution in the context of the scaling up debate: many local participatory institutions have important democratic qualities, but these are difficult to replicate on a larger territorial level (Smith, 2009; Bächtiger and Wegmann, 2014; Bua, 2017). Can these local democratic exercises be scaled up to larger territorial administrations, or can they only exist in small polities, close to citizens?

ACs exist, and have apparently similar logics and characteristics, in polities ranging from small municipalities to large countries. This is the case in countries that have complete systems of ACs developed at each territorial level, such as Brazil or Spain, or where they have a frequent presence, as occurs in some Scandinavian countries (Christiansen et al, 2010). In the case of Spain, ACs were already mentioned in the Constitution of 1978, where there is explicit reference to the national Economic and Social Council. Their expansion continued over the following decades, and they spread throughout other sectoral areas of the national administration, as well as to the regions and local authorities (Navarro, 2004). It is precisely this institutionalisation and similarity in their format and functions that allows the controlled comparison of their existence and functioning on different territorial scales (Avritzer and Ramos, 2016; Bua and Escobar, 2018).

2.2. Do territorial scales matter? 
Dahl and Tufte (1974) connected territorial scale to the functioning of democracy, claiming the virtues of democracy when operating in the nearby local area. More recently, Newton (1982) questioned whether the democratic virtues of the institutions closest to citizens were always better, and Denters et al (2014) systematically examined the uneasy relationship between size and local democracy. Alternative arguments against proximity have been also raised. Innerarity (2006) argues that the current problem of democracy does not lie in the distance between citizens and those who govern. Rather, it lies in an excess of proximity that contaminates public decisions and facilitates clientelism. In an intermediate position, in their analysis of Brazilian ACs, Avritzer and Ramos (2016) show that it is the regional councils that have more deliberative qualities, precisely because of their intermediary role which requires working simultaneously with bottom-up local demands and national considerations. On the whole, previous empirical evidence is contradictory with regards to whether one territorial level will produce better results than the others.

We highlight the role of two arguments that may be related to territorial scale: the nature of the interactions being developed, and the value assigned to different types of objectives and outputs of the councils. Firstly, council members of greater territorial proximity (local) will favour more informal working dynamics and intangible advantages linked to resources, such as mutual knowledge, informality or personal trust. Insofar as councils are understood as spaces for cultivating relationships, exchanging ideas and finding partners and friends to develop other initiatives, smaller polities would be the ideal settings for their development. The types of interactions developed in the ACs are different. The working dynamics of almost all councils 
combine a deliberative period and an aggregative space; a distinction already developed by Mansbridge (1980). The deliberative moment often materialises in committees or working groups where various participants enter into dialogue, while the aggregative space, which is more important in national councils, is necessarily more confrontational, and includes winners and losers. The aggregative logic would understand ACs as an institution where each conflicting interest is voiced through different ideas and votes, building on a decision (Manin, 1997). A more deliberative perspective however, interprets the exchange of ideas not only as a way to make better decisions, but as an end in itself; a process for different actors to know and recognise each other to build a common project. As we will see, the first of these logics prevails in national ACs, whereas the second is more important in those which are local.

The second idea is related to what is understood as policy impact. Part of the scaling up debate departed from the idea that only through incorporating national issues and policies, could participatory institutions achieve impact in important policy fields. Impact comes often at the expense of existing only for small local policies (Font et al, 2018). However, the trade-off in policy may not be between big national issues and small local ones, rather between the different types of influence in the policy cycle. Thus, influence may be defined as incorporating detailed technical issues related to decision and implementation, but also as contributing to a more general discussion, communicating problems and playing an agenda-setting role (Bua, 2017; Pogrebinschi and Ryan, 2017). These different roles may be unequally developed at each territorial level and accorded varying degrees of meaning by participants. 
One final possibility is that differences between territorial levels are almost non-existent, or at any rate, they only have an indirect relationship with the type of territorial administration. This may occur particularly if the councils' structure and roles change substantially at each territorial level. For example, in national councils the interests to be reflected are more complex, resulting in a larger size (e.g., they often include representatives of regional administrations), which can make deliberation more difficult. There are also many regional councils whose reports are mandatory for the development of certain projects, something which occurs less frequently at local level. If this can be used to explain existing differences in the functioning of the councils, it means that the territorial level is not responsible for these differences. Rather it is the various institutional designs, including rules, composition or other crucial differences.

There are three main factors that could also be responsible for important differences: policy areas, institutional design and the personal characteristics of the members. Research about public opinion and policy-making has clearly established that not all policy areas are equally sensitive to citizen input. In the specific world of ACs, Pogrebinshi and Ryan (2017) establish that the type of policy has a clear effect on their potential impact and Alarcón et al (2020) show that environmental councils have a much larger degree of conflict.

Most research about democratic innovations has shown the influence of institutional design as a crucial explanatory variable (Landwher and Holzinger, 2010; Bua and Escobar, 2018). Among the list of potentially influential institutional characteristics, we should at least distinguish between those more closely related to political control, and the bottom-up or top-down approach (Font 
and Galais, 2011; Pogrebinschi and Ryan, 2017). This, as well as other more technical characteristics, such as the number of participants for example, which has been cited as a characteristic which could impede the deliberation process (Brugué and Gallego, 2001; Fishkin, 2009).

Finally, the perceived functioning of any participatory institution could vary significantly depending on the subjective individual position of the interviewee. The differing interests, expectations and positions within the power structures of the institution will clearly affect how each participant interprets and perceives its results and limitations (Jiménez, 2005).

Table 1 summarises the logic and different possibilities to be examined throughout the paper. In sum, we can find three scenarios: 1) No important differences; 2) Differences that may be due to other explanatory factors; 3) Differences that are related to the intrinsic territorial differences between administration levels.

(Table 1)

\subsection{What are the consequences?}

However, before considering if there are any differences, we must discuss where they can be found. Some of the most influential research tends to propose a series of normative criteria against which any participatory institution should be judged. Among them, Fung (2004) or Smith 
(2009) are especially influential, stating a set of relatively similar criteria. Building from their proposals, we suggest a simple division of two main areas.

First of all, we are interested in seeing to what extent the working dynamics of the councils serve to give a voice to different sectors of citizenship and to ensure their presence. Relational aspects among the participants (how they relate to each other, exchange information or deliberate) and their dynamics when discussing and reaching agreements, will be important. To ensure that these institutions have a certain presence and visibility, their ability to be transparent and relate to society as a whole are also crucial (Smith, 2009). The second major component will be the results: topics, reports or recommendations they issue and how these are used or incorporated by public administrations. The operationalisation details are discussed below, after presenting the methodological strategy and the data used.

\section{Methodology}

Spain was chosen as an interesting case for two related reasons. Firstly, Spain has one of the most extended AC systems in the world, and it is possibly the most common type of participatory institution found there. (Navarro, 2004). Secondly, this pattern is extended through all territorial levels, therefore it is an ideal candidate to develop this comparative analysis among them. Furthermore, at the three territorial levels, many of the institutional design characteristics of these institutions are similar. This makes the controlled comparison easier in a constant legal system. 
The first step in gathering the quantitative information was to carry out an extensive mapping of the existing ACs in the national and regional administrations and in the principal municipalities (those with more than 250,000 inhabitants, or more than 175,000 and which are provincial capitals). The search was based primarily on the consultation of each administration's website, complementary searches on the internet and lists provided by the authorities when the internet provided no information. This enabled a total of 2013 councils to be located. This database only includes information on the policy area and the public administration on which each council depends. It serves to provide us with an initial picture and a sample framework from which councils can be selected and studied in more depth.

In order to gain an increased understanding of the functioning of the councils, we needed to consider their regulations and dynamics, as well as their perception by the participants. However, it was not possible to perform this over 2013 councils, so we selected a sample. Our goal was to obtain a selection of councils which would combine certain thematic diversity with a limited range of variability, allowing a comparison between different areas of public policy. To this end, we selected three types of councils: 1) those with a public policy which includes social content and a network of clearly identified and institutionalised actors, such as education councils; 2) those with a less traditional public policy, containing a more heterogeneous network of actors, such as environmental councils; 3) those with a new public policy which is more focused on identity, such as immigration councils. The complete data collection process involved 101 ACs and included a fourth category, neighbourhood councils. However, since their functions and 
composition are especially different, they do not allow a clear cut, direct comparison and are therefore excluded from the analyses developed in this paper. We have sought representation at the three territorial levels, including all councils that existed at national and regional levels and a maximum of one municipal council in each region. The combination of these criteria resulted in a sample of 70 councils.

For each of them we have tried to gather two types of information. Firstly, we coded their main organisational and operational characteristics. This codification has been carried out by a team of three experts using a common code book, with several meetings being held to discuss possible cases where there are uncertainties. We also carried out an online survey of the people who participate in these councils, from which we obtained answers from 501 people, belonging to 55 councils. Five of these councils are at national level, 35 at regional level and 15 are at municipal level. Thirty-one are school councils, 28 are environment councils and 19 are immigration councils. The questionnaire (based on Fobé et al, 2013) is, on average, 23 minutes long and aims to capture the subjective perception of operation and satisfaction with the work carried out in the councils.

The coding of the characteristics of the councils was carried out in the last few months of 2017 and the fieldwork of the survey was developed between November 2017 and March 2018. After an initial contact with the administration responsible for the council, two distinct strategies were used to access the participants. In 27 cases we were able to access the email addresses of the participants and contact them directly, achieving a $30 \%$ response rate. In the remaining 43 
councils it was the head of the council who sent the survey link to the participants, which resulted in a lower response rate, of $12.5 \%$. A systematic comparison of the responses of the people interviewed by one method or another showed no significant differences. In the remaining 23 councils, it was not possible to obtain any response. Among these, we find councils that have not been formally dissolved, but which have not met for years; non-contacts after several attempts; and a few who explicitly refused to participate. In these groups, there are likely to be many councils with poor functioning, therefore the data provided by the survey most likely represents a more optimistic picture than in reality.

In any case, the final sample (Table 2 ) provides an overview of council participants (dominated, as expected, by associative representatives and public administrations), and reflects the expected makeup of the councils according to what their regulations indicate: some overrepresentation in the survey was detected from association members $(36.6 \%$ of the sample when it should be 27.7\%). In any case, the final sample of participants represents the reality of the councils analysed in a relatively fair way.

\section{(Table 2)}

The qualitative materials come from a study of 10 cases of ACs. With a need to maintain a small number of cases, while at the same time facilitating comparability and diversity of the levels of administration, we studied education and immigration councils located in Barcelona and Madrid from the previous selection. These comprised two national councils, four regional councils and 
four local councils. For each of them, documentation was collected and a set of in-depth interviews with participants of diverse profiles were compiled. These included experts, government and opposition politicians and representatives of various associations. The interviews were conducted (recorded and subsequently transcribed) by members of the research team, using a common interview script of between 30 to 60 minutes long on average, between the months of April and October 2018. In total, 64 AC members participated. Table 3 summarises the cases and the profiles of the participant interviewees.

(Table 3)

Regarding the quantitative analysis, and given that our objective is to compare the functioning of the councils across the various dimensions mentioned previously, we chose several indicators as dependent variables that cover the two main areas: working dynamics and results, and satisfaction. For each of them, we selected three indicators: one objective characteristic (coded from rules and/or website) as well as two perceptions of the participants (from the survey). When several indicators on the subject were available, we tried to include them in order to increase their reliability, provided that the statistical indicators (Cronbach) showed that this was possible. Table 4 details the selected variables and their main characteristics.

We highlight three working dynamics that are important to observe: information, interaction and transparency. In the case of the information the participants receive, we use indicators that come from the survey, and refer to satisfaction regarding information. The survey asked about their 
satisfaction with three specific aspects of information: 'sufficient information', 'diverse and balanced information' and 'providing information when requested', through three scales of 1-7 (strongly agree to strongly disagree). Cronbach's alpha of 0.78 shows that it is possible to build a scale by aggregation, so we opted for this. The final variable ranges between the minimum value of 3 and the maximum of 21 .

In the case of interactions, we capture the perception of the interactions among members. As in the previous case, it is the sum of four questions (measured on a 1-7 scale), which refer to: effective communication and constructive interaction between the members; well-structured debate; and the positions of others help me to define my own. Cronbach's alpha is 0.83 .

Finally, in the case of transparency, the information comes from the councils' websites, from where we create a composite indicator of the richness of the information being shown. The variable is a summation of two binary indicators: the online availability of reports prepared by the council, and a website with updated information. To these variables we add a scale ranging from having no website (1), a section on another website (2), a complete website on a different institution's domain (3) or their own website domain resulting in a 1-6 final scale. Cronbach's alpha is 0.76 .

(Table 4) 
In the case of the results, we also use three indicators. For the link to the policies, the council websites allow us to observe their actual objectives, which is our first indicator of the subject. The variable is a summation scale of five dichotomous (0-1) pieces of data. The first, is that the council has an influence on public policies among its explicit objectives (source: law or regulation of creation), and also that it aims to produce 1) an annual activity report; 2) subject reports; 3 ) diagnostic reports; 4) proposals. The Cronbach alpha of the resulting scale based on the five indicators is 0.88 .

The two variables related to satisfaction capture two distinct components. First, satisfaction with the council-made proposals (the sum of four questions measured on a scale of 1-7 relating to: 1) the recommendations are clear; 2) there is a high level of social support; 3) they represent the diversity of the council 4) the satisfaction with the quality of the proposals). Cronbach's alpha of the resulting scale is 0.84 . Second, satisfaction with their influence. This is a summation of five scales. Three of them are scales ranging from 1 (never) to 6 (always) referring to whether the administration is receptive; if it returns information to the council; and if the content of the policies changes. Two are scales ranging from 1-7 that measure the level of agreement, with the participant's contributions being taken into account and the proposals being taken into account. Cronbach's alpha is 0.86 .

Our main objective is to see if there are differences in the functioning and results of the councils depending on the territorial levels where they operate, and if these differences cannot be attributed to other characteristics. Therefore, the first step will be to observe if there are 
differences between what happens in national, regional and local administration councils. Subsequently, we verify whether these differences are upheld when we control for other variables. Table 5 collects information about our independent variables. In addition to the territorial level, which is our main independent variable, we include five other basic pieces of information about the councils' institutional design. These could also be responsible for some of the differences, corresponding to the three main areas described above: policy area, institutional design and type of participant. Firstly, the sectorial scope, which distinguishes the three policy areas (education, environment and immigration). Secondly, three variables measure institutional design: the level of control that the administration has over its board, the percentage of members of the public administration over the total members of the council, and the number of council plenary members (size). With regards to the level of control over its board, we assign a relative weight to each position based on its importance. The presidency in the hands of someone who does not belong to that public administration has a value of 3 , the first vicepresidency a value 2 and the second vice-presidency a value 1 and then we add them together. Thus, the theoretical maximum value would be $6(3+2+1)$, but the real maximum value of the variable is 5. Finally, we also consider the type of participant, as to whether they belong to public administration, civil society or other sectors.

(Table 5)

We start by checking the relationship of these variables against the different territorial levels of administration. We will then carry out a linear regression analysis for each of the dependent 
variables. This strategy allows us to observe whether territorial differences continue to be important once we control for a set of alternative explanations. In any case, our main focus is on whether the territorial level variable matters, without an in-depth analysis of the role played by control variables.

Where the territorial level continues to appear as relevant, we go on to analyse the qualitative interviews in depth, to look for explanations of these differences. Specifically, the analysis carried out focused on the opinions and information expressed by the interviewees regarding the functioning of the councils in which they participate and their "results". Nvivo was used to code and select relevant texts which were treated within a comprehensive or socio-hermeneutic conception of the analysis.

\section{Quantitative analysis}

How far do councils differ at varying levels of government, based on the variables analysed? Graphs 1 to 3 show the distribution of the indicators used. Two ideas prevail. The first, is that there are more similarities than differences in the reality of the different territorial levels, with distributions that are not radically different in the majority of variables. The second, is that the existing differences tend to point in similar directions: relatively better results in local and/or regional councils. The only clear exception to this dominant pattern appears in Graph 2, where transparency is lower in local cases.

(Graphs 1 to 3) 
To test if the existing differences are related to the territorial level or whether they can be explained through other features of the councils' institutional designs, we carried out a series of multiple regressions with the set of variables studied as dependent variables. We used the territorial level as an explanatory variable, together with the other control variables mentioned above. Table 6 summarises the results of these regressions.

(Table 6)

To sum up, territorial level matters for the four perceived characteristics, with local and regional councils achieving better results, even when controlling for council institutional design. This is not the case for the two objective characteristics (transparency and outputs). The reason does not seem to be related solely to the smaller $\mathrm{n}$ of the analysis, since other explanatory variables are significant in spite of the small sample size. Thus, the significant results in the subjective variables appear to be due to a more positive environment in the subnational councils, which favours these enhanced perceptions.

The coefficients are larger and are clearly more significant for some characteristics (e.g., satisfaction with influence) than for others (e.g., satisfaction with information), but they are significant and positive for both regional and local councils in the four subjective variables. Although the control variables appear as important in many cases (the sectoral content of the councils in particular, but in some cases also other institutional design characteristics, or the profile of the person interviewed), its introduction does not lessen the importance of the 
territorial level. In the following section we analyse the interviews carried out in 10 councils, to look for interpretive clues as to why regional and local level satisfaction is higher.

\section{Why do territorial differences appear? Contributions from case studies}

As with the previous quantitative results, the interviews show more similarities than differences between territorial levels. However, there are differences which call for an interpretation of the results that show better satisfaction of local and regional ACs. Firstly, the interviewees positively assess the relationships with other members of the same $A C$ and mention them as a reason for satisfaction. They highlight that one of the main reasons for their satisfaction is the nature of the ACs; they are places to meet with people who have similar areas of interest. Relational goods of all kinds are valued, from meeting politicians, to building personal relationships, or establishing alliances and common programs with other local associations. A positive assessment of the importance of the relationships between council members is given in practically all the councils. However, it appears to be more widespread and has greater emphasis in the opinions of the participants in local councils, particularly when compared to those expressed by the participants in national councils (in the regional councils a greater diversity is found in each specific case).

"Well, yes, it is good, because among the entities we all know each other; relationships are formed and at that level it is a good thing."

(Municipal Immigration Council of Barcelona, Association) 
"We think it is very important to have this platform, to coordinate with other groups that are working for education."

(Local Education Council of Barcelona, Association)

"Sure, you establish contacts and build synergies, prepare shared actions and establish new relationships that you wouldn't otherwise have."

(Catalan Immigration Council, Association)

One of the reasons for the differing assessment of relations between members of the ACs appears to be in the less formal nature of some councils, particularly local ones. They allow a greater flexibility of participation mechanisms and greater possibilities for participation in more deliberative settings, such as commissions or working groups. In other words, those which promote greater closeness and a more continuous and intense relationship among their members. This is in contrast with the more "political" and confrontational dynamics, based on the logic of the adversary, which predominate in national councils. Indeed, the perception of the existence of antagonistic blocks within the councils is greater in those at national level. This can cause greater difficulties or even personal withdrawal.

"You don't vote. We are more or less all in agreement. And there is a good atmosphere, I have the feeling that you can tell there are no quarrels between us..."

(Madrid Education Board, Teachers) 
"The corporate interests of the different members ended up generating a discussion of an ideological or political nature, and not enriching the process (...) it was a bit boring in the end, to see how the defence of interests overshadowed the fight for quality or for finding solutions, or contributing something. In the end it was about being against the Ministry, or with the Ministry." (National School Council, Former President)

There is also broad agreement among interviewees that the perceived influence of ACs is quite limited. Their consultative nature is generally assumed, and it is implicitly accepted that any attention given to recommendations and opinions is at the discretion of the administration. However, beyond this general agreement, there are also some significant differences, in that people who participate in the local councils feel that they have a greater degree of influence in these local councils.

This perception can be considered strange or paradoxical when we consider that national and regional councils are more likely to have a mandatory recognised function for issuing opinions regarding legal texts which affect their area. In this sense, the perception of the influence of local councils refers mostly to two issues: their ability to become spokespersons or speakers for social demands; and the promotion or revitalisation of public debates on the issues they address. These influences are also perceived in national (and regional) councils, but less clearly. Devoting a considerable part of their activity to the mandatory reporting of legal texts means that proactive activities and those done through their own initiative become weaker. In other words, by dedicating less time to issuing opinions or reporting legal texts, local councils "free themselves 
up" to dedicate more time towards activities which transmit social demands and revitalise social debate. Detailed policy influence may be sacrificed to achieve what is considered as a more powerful agenda-setting role. Paradoxically, this means that by having fewer mandatory attributions, their perception of meaningful social influence is increased.

"When healthcare cards were introduced, it was indeed influential and effective (...) it made an impact. (...) I think there are actions which have been great, influential proposals." (Municipal Immigration Council of Barcelona, Association)

"Up to now, most of the issues we have raised, that have been discussed, are being incorporated."

(Madrid Education Board, Association)

"The people in the council were engaged, therefore we had some very intense debates. In that respect it was very interesting. (...) For information, and even critical analysis of the management of education, it is a good instrument."

(Barcelona School Council, political representative)

\section{Discussion}

In this section we begin by summarising the empirical findings and discussing what they add to the theoretical framework suggested above. We then discuss some of the limits of the research 
and suggest prospects for further research. We finish by discussing some implications for democratic theory and for the debate on scaling up participatory institutions.

Although there are more similarities than differences between councils at their various territorial levels, relevant nuances exist between the realities seen in the different administrations. On a purely descriptive level, most of the quantitative indicators show differences which point to more promising dynamics and results in local and regional areas. In contrast, national councils are less favoured in this picture, except in the transparency of the work they develop. When the analysis takes into account the institutional design of the councils, such as their size and composition, some of the territorial differences vanish. However, a general pattern can still be seen in the greater levels of satisfaction in local and regional councils.

The fit between quantitative and qualitative results is mostly reassuring, but it also presents some differences. On one hand, the 10 case studies allow us to understand more effectively how and why differential dynamics are developed between councils which are closer to citizens (local) and those which are more formalised and distant (national). On the other hand, the interviews seem to situate the regional level in between both realities, while quantitative analyses are pointing to results at regional level that closely resemble those of local level.

If we decided to trust the result that the qualitative analysis points to, the local scale would be the most favourable scenario for the development of these participatory institutions, or at the very least, for achieving satisfaction from their participants. The councils would encounter 
greater difficulties as their territorial scope of reference increased. These results would be consistent with a long tradition of thought, which links proximity to citizen participation (Dahl and Tufte, 1974). Local councils, despite being formally similar to regional and national councils, have an advantage in the richness and fluidity of relationships, both between the council members themselves and with the political and administrative authorities. Therefore, proximity could improve the functioning of the councils, to the extent that they can operate in a climate of greater mutual knowledge, facilitating relations between the various actors. The emphasis on the importance of the relational aspect, points to a conclusion which is coherent with much of the literature on decentralisation (Burns et al, 1994), participation from below (Uhlaner, 2014) or from above (Bherer et al, 2019) and network organisations (Goldsmith and Eggers 2004). The network of relationships becomes a crucial asset being formed in these interactions: it provides important information (for policy or to help the organisation develop), allies from similar groups, and crucial recognition from authorities (Gamson, 1975).

The participants interviewed in our case studies have a higher appreciation of more deliberative activity, which exists for most participants in local councils, yet only reaches a few people in the larger national councils. This differentiation works in favour of proximity, since deliberative moments are considered more interesting (and less problematic) than mere aggregative votes. In this regard, it can be argued that voting in plenary tends to provoke a confrontation between interests and reinforces the logic of antagonistic blocks. The comfort generated by more informal deliberative spaces can also be noted, in contrast to the more formal, confrontational, and stagnant dynamics of the aggregative spaces. The councils have a necessarily dual nature, but at 
least some of the participants value the deliberative nature more positively (gaining advantage in environments of proximity) than the aggregative one (better adapted to larger territorial areas). The more political nature of the discussion on national councils means that conflict cannot be avoided, and the adversarial nature of politics (Mansbridge, 1980) makes itself more present. This generates more negative feelings, a result which resonates with previous findings in different research areas (Hibbing and Theiss-Morse, 2002; Eliasoph, 2009). The more pleasant nature of personal interactions found in the local councils, where positive feelings of being in agreement and being recognised by others are much more widespread, are more likely to generate satisfaction among participants.

Regarding the receptivity of the decisions that the council transfers to government authorities, the general perception that emerges from surveys and interviews is more positive than most previous research suggests (Sintomer and Maillard, 2007; Hendriks et al, 2013). Their decisions are received by the institution, but in a selective and discretionary manner. This creates a sense of uncertainty about the effective fate of these decisions, especially regarding the political treatment they will receive. Institutional receptivity in regional (and sometimes national) councils is often formalised through the drafting of mandatory reports, while in the local councils there are no clear channels through which to discuss council proposals. This difference, which could be viewed as a disadvantage, is presented from an alternative point of view through the interviews: while the mandatory reports reinforce the reactive logic of their debates and decisions, local councils channel proactivity and the capacity to act as a conveyor belt for community problems and debates. In this way, local councils are creating space not only for their own initiatives, but 
also for the pressures of civil society (Warren, 2001). They appear as a potential space for political debate and democratic strengthening against the technocratic formalism of other territorial spheres. Faced with the more technical policy detailed advice and professional discussion of the national councils, the expectations raised by these local participatory institutions are more in the political-democratic sphere. It is not only their ability to draft precise opinions, but their capacity to articulate the demands of citizens (Cooper \& Musso, 1999) and to encourage public debates. The fact that they do not need to answer questions from the administration can be used to their advantage; they are able to raise their own. This is a conclusion similar to that reached by Bua (2017) in the British SCA case and resonates with recent research questioning the different meanings of deliberative outcomes (Jacquet \& Van der Does, 2020).

These dynamics appear to facilitate a greater personal satisfaction among council members, with differing levels of satisfaction depending on the proximity between the council and the community they seek to represent. At the risk of over-simplification, we could differentiate between councils that aspire to operate as spaces for technical-professional consultation, and those that seek to channel debates and political conflicts that, according to associations, occur in the community. The diversity of possible outcomes of participatory institutions that Goodin and Dryzek mention (2006) also appears in this case: greater territorial scale offers advantages for the first version, while the local scale of proximity can be more readily linked to the second.

Among the limitations and open questions resulting from this study, there are at least two which should be mentioned. Firstly, the control variables used in the quantitative analysis are, in some 
cases, of considerable importance and require further research. Council boards which are controlled to a lesser extent by the administration usually obtain better results. Even if Spanish ACs are, in general, top-down institutions, incorporating more bottom-up characteristics appears to improve their results, as previous research indicates (Cooper \& Musso, 1999; Fung, 2004; Font \& Galais, 2011). This suggests they work better if perceived as being more independent from the administration. Environmental councils appear to be more problematic. We do not have the empirical evidence necessary to fully understand this outcome, but the strong polarisation that often appears in these councils (Jiménez, 2001) could be one of the reasons that will help us understand the more negative experience they face.

Secondly, in between the polarity of local versus national councils, regional councils are placed in an ambiguous position. A number of their objective values are clear; they obtain the same high level of results as local councils in many of the subjective indicators used. Despite this, the satisfaction recorded in the interviews is more irregular, therefore suggesting that the intermediate territorial level is far from an ideal setting for participation, as presented by the Brazilian case (Avritzer and Ramos, 2016). The advantages and limitations of institutions in capturing citizens' voices at these intermediate territorial levels should be further explored in comparative perspective.

The most positive perceptions at local and regional levels are evident in some characteristics, but not in all of them. Non-significant differences in some cases, or even a reverse pattern regarding 
transparency, act as a reminder for caution and a call for further research with additional measurements.

Finally, the external validity of these results, beyond those of the Spanish ACs, should also be considered. The similarities between some of the results, such as the crucial role of personal contacts or of agenda-setting, presented along with other international cases, should be interpreted as clear signs of an extended validity of these claims, beyond its particular setting. On the other hand, the considerable international diversity of the institutions we have called ACs, not to mention the much larger and diverse field of participatory institutions, clearly points in the direction that differences related to institutional design will exist among countries. Only by increasing the diversity of the cases analysed will we be able to provide a clear answer to this question. Thus, the role played by the regional level ACs may be particular of Spain and other highly decentralized countries, but most of the overall argument about proximity and relational goods is likely to hold in many polities.

These results have important implications for three larger democratic debates: the meanings and contents of democracy; the possible scaling up of participatory institutions; and their potential democratic and policy related roles. First, the tensions we have explored in ACs reflect larger debates about democratic ideals, and the role that voting and public debate should play. For example, Green (2010) discusses the contrast between a democratic model traditionally based on the "voice", and an increasing tendency to give priority to the "eyes". Local councils adopt a greater "voice" approach in their functioning, providing a central role for public debate and 
building collective projects. On the other hand, in national councils there is a greater presence of "eye" based ideals, where participants (at least in plenary sessions) are more limited in how they express their individual preferences in supporting or rejecting, as spectators, the ideas put forward by political leaders. Green's positive assessment of this change contrasts with the reality of how ACs work and the existence of the apparently increased desire of their participants to go beyond the role of spectator. AC participants also have the desire to become involved in more difficult, yet more enjoyable, deliberative roles (Neblo et al, 2010).

In any case, the prevailing idea that voice and public debate are increasingly difficult in larger communities has also appeared in the analysis of ACs. National councils have to incorporate more diverse actors (e.g., the regions), and group size facilitates moving from deliberative to purely aggregative dynamics. Their greater media visibility also facilitates a clear emergence of confrontational party-related logics in their work, provoking more negative feelings among most of their participants. An additional pessimistic reading of this result would be to consider it as a trade-off, from which there is no easy escape: the institution will always be limited by its size, and its expansion may be beneficial in order to incorporate new sectors or more diversity. This, however, will almost necessarily play against its deliberative possibilities.

On the other hand, a more positive reading of the results does exist: ACs are one of the most easily reproduced participatory institutions in larger communities, and their results are not dramatically different from those reached at local level. Considering that any alternative is far from perfect (no deliberation in purely plebiscitary institutions, aggregation difficulties in regional 
level participatory budgeting, legitimacy difficulties or limited policy effect in large scale minipublics, and so on), ACs emerge as a serious alternative which should be considered when the scaling up of participatory institutions is addressed. While in Brazil's case this is solved through large temporary Policy Conferences (Pogrebinschi and Ryan, 2017), in Spain this role is played by permanent national councils that, on average, are only slightly larger than local councils. In fact, the Spanish case and the associational and neo-corporatist tradition it represents (Christiansen et al, 2010) is of added interest to this debate, as these national institutions are not the result of an uneasy adaption to the national context of local institutions. Their diffusion may have travelled the other way around, from national to local setting, ensuring they have a long trajectory at national level. Their institutional engineering, combining their more aggregative spaces (plenaries), and their deliberative dynamics in working groups, executive committees and so on, represents an attempt to allow the development of these two logics, in two different settings, within the same institution. Simply put, in the absence of a perfect alternative, ACs can provide a valid option if the scaling up of participatory institutions is treated as an important consideration in the judgement of them (Smith, 2009).

Finally, solving the problem of scaling up may require the prior resolution of another crucial dilemma: what is the main role to be played by these institutions? An important part of the research tradition, from the classical study of Arnstein (1969) through to the recent analysis of Font et al (2018), places policy influence and implementation as crucial standards against which these institutions should be judged. The quantitative and qualitative assessments made here, demonstrate that these are not the only criteria considered important by participants. Most of 
them agree that the ACs' influential capacity is limited, but they accept this role as it has been made clear since their creation. The appearance of "participatory frustration" (FernándezMartínez et al, 2019) has a greater connection to unfulfilled promises than to the modest objectives of these institutions. Participants tend to appreciate that they can perform different democratic roles (Goodin and Dryzek, 2006; Jaske and Setälä, 2019) and that some of them, such as agenda-setting or public debate, may be just as interesting (see also Bua, 2017) as the role of making final decisions about detailed policy solutions. 


\section{References}

Alarcón, P., Fernandez-Martínez, J.L. \& Font, J. (2020): Comparing Environmental Advisory Councils: How They Work and Why it Matters. Sustainability 2020, 12, 4286.

Arnstein, S. (1969). "A ladder of citizen participation", Journal of the American Planning Association, 35 (4): 216-224.

Avritzer, L. and Ramos, A. 2016. “Democracia, escala y participación. Reflexiones desde las instituciones participativas brasileñas", Revista Internacional de Sociología, 74 (3), http://dx.doi.org/10.3989/ris.2016.74.3.040.

Bächtiger, A. and Wegmann, A. 2014. "Scaling up deliberation", in Elstub, S. and McLaverty, P. (eds): Deliberative democracy. Issues and cases. Edinburgh: Edinburgh University Press, pp 118135.

Berry, J., Portney, K. and Thomson, K. (1993). The Rebirth of Urban Democracy, Washington: The Brookings institution.

Bherer, L., Fernández-Martínez, J. L., García Espín, P., Jiménez Sánchez, M., (2016). “The promise for democratic deepening: The effects of participatory processes in the interaction between civil society and local governments". Journal of Civil Society, 12(3), 344-363.

Brugué, J. and Gallego, R. 2001. “¿Una administración pública democrática?", in Font, J (ed): Ciudadanos y decisiones públicas, Barcelona: Ariel.

Bolitho, A. 2013. The role and future of citizen committees in Australian local government, University of Technology, Sydney.

Bua, A. 2017. "Scale and policy impact in participatory-deliberative democracy: lessons from a multi-level process", Public Administration, 95 (1): 160-177.

Bua, A \& Escobar, O. (2018) "Participatory-deliberative processes and public policy agendas: lessons for policy and practice", Policy Design and Practice, 1:2, 126-140.

Burns,D., Hambleton, R. and Hoggertt,P. 1994. The Politics of Decentralisation. Revitalising Local Democracy. Londres: Macmillan. 
Campos, J. and J. González. 1999. "Deliberation councils, government-business-citizen partnerships, and public policy-making: Cases from Singapore, Malaysia, and Canada." Asia Pacific Journal of Management, 16.3, pp. 429-448.

Cooper, T. and J. Musso. 1999. "The potential for neighborhood council involvement in American metropolitan governance." International Journal of Organization Theory and Behavior, 2, pp. 199232.

Carvalho,M.C. and Teixeira.A.C. 2000. "Conselhos Gestores de Políticas Públicas”, Polis no 37, pp. 99-119.

Christiansen,P., Norgaard,A., Rommetvedt,H., Svensson,T.G. and Öberg,P. 2010. "Varieties of democracy. Interest groups and corporatist committees in Scandinavian policy making", Voluntas: International Journal of Voluntary and Nonprofit Organization. 21 (1), pp. 22-40.

Dahl, R; Tufte, E. 1974. Size and democracy, Stanford: Stanford University Press.

Denters, B. et al .2014.: Size and local democracy, Edward Elgar Publishing.

Eliasoph, N. Avoiding politics, Cambridge: Cambridge University Press.

Fernández-Martínez, J.L.; García-Espín, P., Jiménez, M. 2019. “Participatory frustration: the unintended cultural effect of local democratic innovations", Administration \& Society, 52 (5), 718748.

Fishkin, J (2009). When the people speak: deliberative democracy and public consultation, Oxford: Oxford University Press.

Fobé, E., Brans, M., Vancoppenolle, D. and Van Damme, J.. 2013. Institutionalized advisory systems: An analysis of member satisfaction of advice production and use across 9 strategic advisory councils in Flanders (Belgium). Policy and Society, 32(3), 225-240.

Font, J.\& Galais, C. 2011. "The qualities of local participation: the explanatory role of ideology, external support and civil society as organizer", International Journal of Urban and Regional Research, 35 (5): 932-948.

Font, J.; Smith, G.; Galais, C.; Alarcón, P. 2018. “Cherry-picking participation: explaining the fate of proposals from participatory processes", European Journal of Political Research, 57 (3), 615-636. 
Fung, A. 2004. Empowered participation. Reinventing urban democracy. Princeton: Princeton University Press.

Gamson, W.A. 1975. The strategy of social protest. Homewood: Dorsey Press.

Goldsmith,S. and Eggers,W.D. 2004. Governing by Network. The New Shape of the Public Sector. Washiongton DC: The Brooking Institution.

Goodin R and Dryzek J. 2006." Deliberative Impacts: The Macro-Political Uptake of Mini-Publics". Politics \& Society. 34(2):219-244.

Green, J.E. (2010) The Eyes of the People. Democracy in an Age of Spectatorship. Oxford: Oxford University Press.

Hendriks, C.; Bolitho, A. and Foulkes, C. 2013. "Localism and the paradox of devolution: Delegated citizen committees in Victoria, Australia". Policy Studies, 34(5-6), 575-591.

Hibbing, J. \& Theiss-Morse, E. 2002. Stealth Democracy: Americans' Beliefs About How Government Should Work, Cambridge: Cambridge University Press.

Innerarity, D. 2016. El Nuevo espacio público. Madrid: Espasa.

Jacquet, V. and Van der Does, R. 2020 'Deliberation and Policy-Making: Three Ways to Think About Minipublics' Consequences', Administration \& Society, online first,1-20

Jaske, M. \& Setala, M. 2019. "A Functionalist Approach to Democratic Innovations", Representation, DOI: 10.1080/00344893.2019.1691639

Jiménez M. "Sustainable Development and the Participation of Environmental NGOs in Spanish Environmental Policy". In Environmental Politics in Southern Europe; Eder, K., Kousis, M., Eds.; Environment \& Policy, Springer, Dordrecht, 2001; Volume 29, 225-253.

Landwher, C.; Holzinger, K. 2010. "Institutional determinants of deliberative interaction". European Political Science Review, 2 (3), pp. 373-400.

Manin, B. 1997. The principles of representative government, Cambridge: Cambridge University Press. 
Mansbridge,J. 1980. Beyond Adversary Democracy. Chicago: Chicago University Press.

Navarro, C. 2004. "Participatory democracy and political opportunism: municipal experience in Italy and Spain (1960-93)", International Journal of Urban and Regional Research, 28 (4): 819-38.

Neblo, M.; Esterling, K., Kennedy, R; Lazer, D. 2010. "Who wants to deliberate- and why?", American Political Science Review, 104 (3); 566-583.

Newton, K. 1982. "Is small really so beautiful? Is big really so ugly? Size, effectiveness, and democracy in local government", Political Studies, 30 (2): 190-206.

Pogrebinschi, T. \& Ryan, M. 2017. "Moving beyond input legitimacy: when do democratic innovations affect policy-making?", European Journal of Political Research, 57 (1): 135-152.

Serdült, U. and Y. Welp. 2015. "How Sustainable is Democratic Innovation? Tracking Neighborhood Councils in Montevideo", Journal of Politics in Latin America, 7, 2, 131-148.

Sintomer, Y. and J. De Maillard. 2007. The limits to local participation and deliberation in the French 'politique de la ville'. European Journal of Political Research, 46(4), 503-529.

Smith, G. 2009. Democratic innovations. Designing institutions for citizen participation. Cambridge: Cambridge University Press.

Uhlaner, C. 2013. "Relational goods and resolving the paradox of political participation", Recerca, 14 , pp. 47-72.

Warren, M. 2001. Democracy and association. Princeton: Princeton University Press. 
Graph 1. Assessment of information and interaction, by government levels

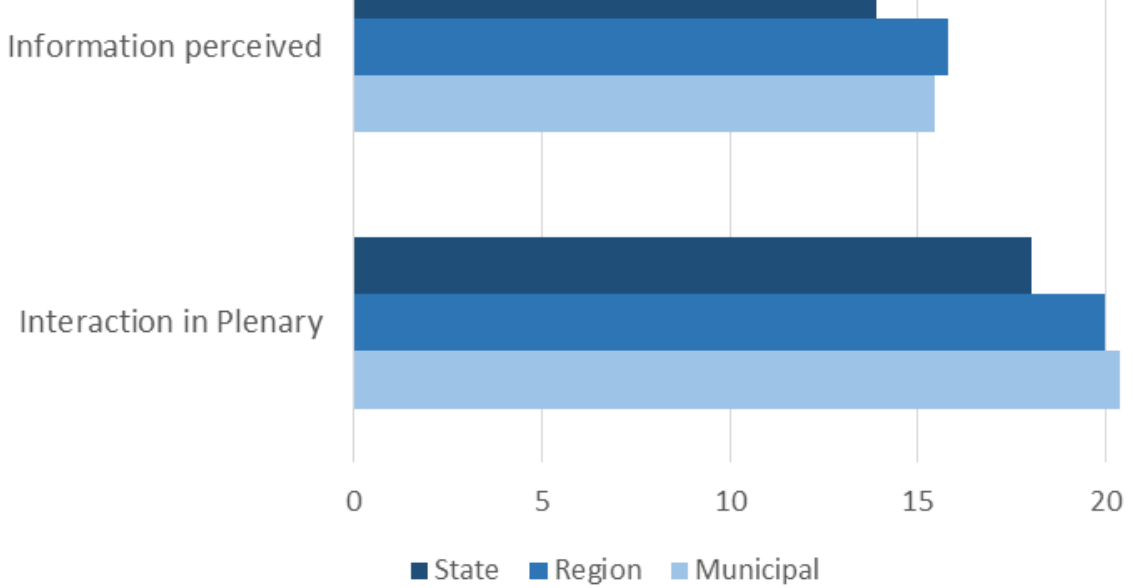

Graph 2. Transparency and outputs, by government levels

Outputs and objectives

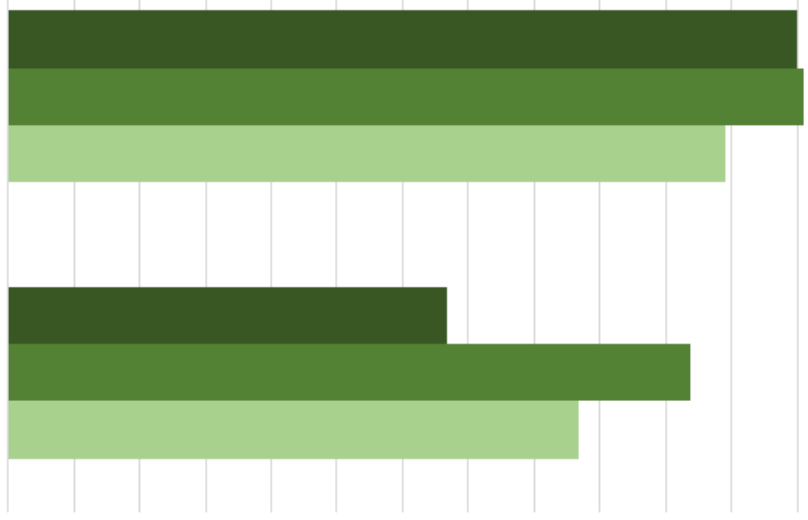

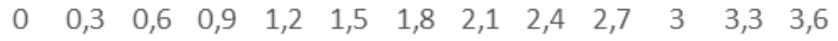

- State Region municipal 
Graph 3. Satisfaction with proposals and influence, by government level

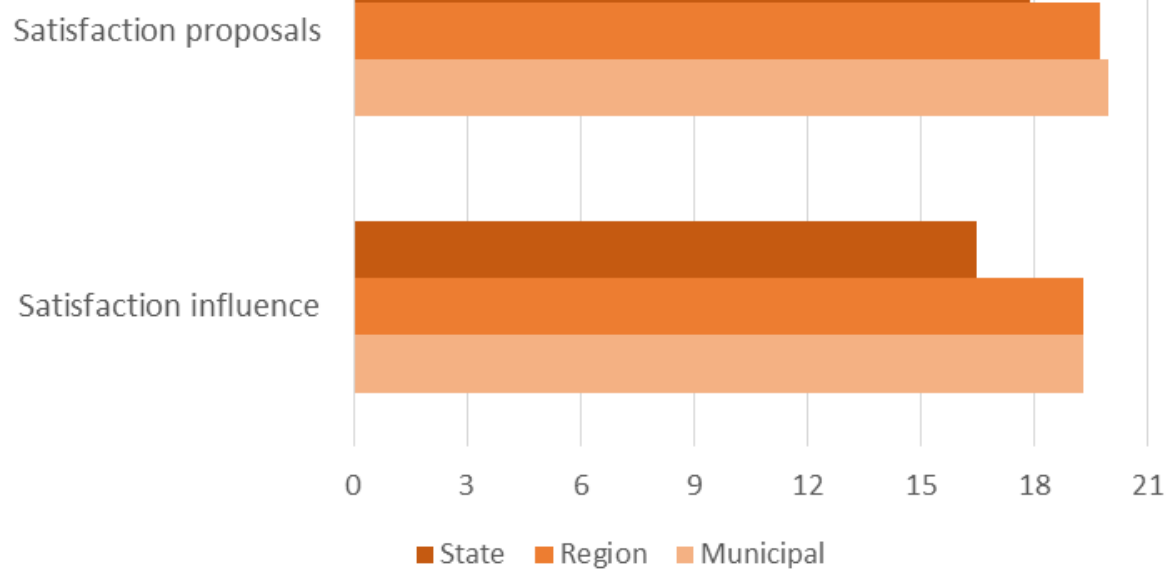

Table 1. Explanatory logic of the paper

\begin{tabular}{|c|c|c|}
\hline Possible results & Main explanatory factor & Causal mechanisms \\
\hline No differences & - & - \\
\hline \multirow{2}{*}{ Territorial differences } & Other explanatory factors & $\begin{array}{c}\text { Policy area, institutional design } \\
\text { or types of participants, explain } \\
\text { all the relevant differences found }\end{array}$ \\
\cline { 2 - 3 } & Territorial level factors & $\begin{array}{c}\text { Different nature of interactions } \\
\text { (relational goods) }\end{array}$ \\
\cline { 2 - 3 } & & $\begin{array}{c}\text { Different types of policy impacts } \\
\text { at each territorial level }\end{array}$ \\
\hline
\end{tabular}


Table 2. Comparison between the expected profile of the persons to be interviewed and the sample obtained

\begin{tabular}{|l|l|l|l|}
\hline & \% in survey & \% in official makeup & Difference \\
\hline Public administration & 28.8 & 31.1 & -2.3 \\
\hline Experts & 7.9 & 8.7 & -0.8 \\
\hline Associations & 36.6 & 27.7 & 8.9 \\
\hline Unions and business organisations & 23.7 & 21.6 & 2.1 \\
\hline Representatives from other councils & 0.7 & 5.7 & -5.0 \\
\hline Others & 2.3 & 5.2 & -2.9 \\
\hline
\end{tabular}

Table 3. Qualitative case studies: cases and interviewees

\begin{tabular}{|c|c|c|c|c|}
\hline \multirow[t]{2}{*}{ Territory } & \multirow[t]{2}{*}{ Policy } & \multicolumn{3}{|c|}{ Profiles and number of interviewees } \\
\hline & & $\begin{array}{c}\text { Administration } \\
\text { (politician or public officer) }\end{array}$ & Stakeholders & $\begin{array}{c}\text { Other } \\
\text { (opposition or experts) }\end{array}$ \\
\hline \multirow{2}{*}{ National } & Education & 2 & 4 & 2 \\
\hline & Immigration & 2 & 3 & 2 \\
\hline \multirow{2}{*}{ Madrid Region } & Education & 2 & 4 & 2 \\
\hline & Immigration & 1 & 3 & 2 \\
\hline \multirow{2}{*}{ Catalonia } & Education & 1 & 2 & - \\
\hline & Immigration & 2 & 4 & - \\
\hline \multirow{2}{*}{ City of Madrid } & Education & 2 & 5 & 1 \\
\hline & Immigration & 1 & 3 & 2 \\
\hline \multirow{2}{*}{ Barcelona } & Education & 2 & 2 & 2 \\
\hline & Immigration & 2 & 2 & 2 \\
\hline
\end{tabular}


Table 4. Dependent variables. Principal descriptive features

\begin{tabular}{|l|l|l|l|l|l|l|l|}
\hline Dimension & Variable & Average & Max & Min & SD & Cronbach & Source \\
\hline $\begin{array}{l}\text { Working dynamics } \\
\text { (information, interaction and } \\
\text { transparency) }\end{array}$ & $\begin{array}{l}\text { Information } \\
\text { perceived }\end{array}$ & 15.5 & 21 & 3 & 4.2 & 0.86 & Survey \\
\cline { 2 - 8 } & $\begin{array}{l}\text { Interaction } \\
\text { plenary }\end{array}$ & 19.9 & 28 & 5 & 4.6 & 0.75 & Survey \\
\cline { 2 - 8 } & $\begin{array}{l}\text { Transparency } \\
\text { general }\end{array}$ & 3.5 & 6 & 1 & 1.6 & 0.76 & $\begin{array}{l}\text { Council } \\
\text { website }\end{array}$ \\
\hline Results and satisfaction & $\begin{array}{l}\text { Outputs and } \\
\text { objectives }\end{array}$ & 2.9 & 5 & 0 & 2 & 0.88 & Regulations \\
\cline { 2 - 8 } & $\begin{array}{l}\text { Satisfaction } \\
\text { proposals }\end{array}$ & 19.6 & 28 & 4 & 4.6 & 0.84 & Survey \\
\cline { 2 - 8 } & $\begin{array}{l}\text { Satisfaction } \\
\text { influence }\end{array}$ & 19 & 32 & 5 & 5.5 & 0.86 & Survey \\
\hline
\end{tabular}


Table 5. Independent variables: categories and descriptive statistics

\begin{tabular}{|c|c|c|c|c|c|}
\hline $\begin{array}{l}\text { Variable } \\
\text { Reference category in regression }\end{array}$ & Min & Max & Average & SD & Response categories \\
\hline $\begin{array}{l}\text { Territorial level } \\
\text { National }\end{array}$ & 1 & 3 & & & $\begin{array}{l}\text { Categorical: } 1 \text { national; } 2 \text { region, } 3 \\
\text { municipality }\end{array}$ \\
\hline $\begin{array}{l}\text { Council subject area } \\
\text { Education }\end{array}$ & 1 & 3 & & & $\begin{array}{l}\text { Categorical: } 1 \text { education, } 2 \\
\text { immigration, } 3 \text { environment }\end{array}$ \\
\hline $\begin{array}{l}\text { Bottom-up council board (not } \\
\text { controlled by the administration) }\end{array}$ & 0 & 5 & 1.4 & 1.8 & $\begin{array}{l}\text { Continuous } 0 \text { (absolute control) to } \\
5 \text { (without control) }\end{array}$ \\
\hline $\begin{array}{l}\text { Makeup: Percentage of } \\
\text { administration members }\end{array}$ & 1.6 & 57.7 & 21.6 & 13.2 & Continuous (percentage) \\
\hline Size. Number of members & 17 & 127 & 49 & 25.1 & $\begin{array}{l}\text { Continuous (absolute number of } \\
\text { members) }\end{array}$ \\
\hline $\begin{array}{l}\text { Type of member } \\
\text { Others }\end{array}$ & 1 & 3 & & & $\begin{array}{l}\text { Categorical: } 1 \text { administration; } 2 \\
\text { association/citizen; } \\
3 \text { other }\end{array}$ \\
\hline
\end{tabular}

Note: All variables are used in all regression models, except type of member that is only incorporated when using survey data 
Table 6. Results of regression analysis: Explanatory coefficients of local and regional levels in multiple regressions (linear or logistic, depending on the case)

\begin{tabular}{|c|c|c|c|c|c|c|}
\hline Dimension & Variable & $\begin{array}{l}\text { Coef B } \\
\text { Regional }\end{array}$ & $\begin{array}{l}\text { Coef B } \\
\text { Local }\end{array}$ & $\begin{array}{l}\text { Other significant variables in the model }(p<.05 \text {, } \\
\text { negative coefficients underlined) }\end{array}$ & $\mathbf{R 2}$ & $\mathbf{n}$ \\
\hline \multirow[t]{3}{*}{$\begin{array}{l}\text { Working dynamics (information, } \\
\text { interaction and transparency) }\end{array}$} & $\begin{array}{l}\text { Information } \\
\text { perceived }\end{array}$ & $0.19 *$ & $0.20 *$ & $\begin{array}{l}\text { Environment, Council board, Member of administration } \\
\text { Member of civil society }\end{array}$ & 0.13 & 500 \\
\hline & Interaction plenary & $0.27 * *$ & $0.18 *$ & Council board, Environment, Member of civil society & 0.13 & 500 \\
\hline & $\begin{array}{l}\text { Transparency } \\
\text { general }\end{array}$ & -.31 & -.51 & Environment, Immigration, Council board & 0.63 & 54 \\
\hline \multirow[t]{3}{*}{ Results and satisfaction } & $\begin{array}{l}\text { Outputs and } \\
\text { objectives }\end{array}$ & 0.17 & -0.05 & Environment, size & 0.71 & 54 \\
\hline & $\begin{array}{l}\text { Satisfaction } \\
\text { proposals }\end{array}$ & $0.19 *$ & $0.25 * *$ & $\begin{array}{l}\text { Council board, Member of administration, Member of } \\
\text { civil society }\end{array}$ & 0.13 & 500 \\
\hline & $\begin{array}{l}\text { Satisfaction } \\
\text { influence }\end{array}$ & $0.23^{* *}$ & $0.27 * *$ & Council board, Member of administration & 0.18 & 500 \\
\hline
\end{tabular}

\footnotetext{
$* * p<.01, * p<.05$
} 